UDC 577.181.5+57.085.23+633.111

\title{
Effect of Ceftriaxone and Timentin antibiotics on morphogenetic processes in the in vitro culture of bread wheat Triticum aestivum $\mathrm{L}$.
}

\author{
M. A. Bannikova ${ }^{1,2}$, I. R. Gorbatyuk ${ }^{1}$, I. S. Hnatiuk ${ }^{1,2}$, L. V. Malysheva-Otto ${ }^{3}$, V. P. Duplij ${ }^{1}$ \\ ${ }^{1}$ Institute of Cell Biology and Genetic Engineering, NAS of Ukraine \\ 148, Akademika Zabolotnoho Str., Kyiv, Ukraine, 03680 \\ ${ }^{2}$ National Technical University of Ukraine «Kyiv Polytechnic Institute», \\ 37, Pobedy Av., Kyiv, Ukraine, 03056 \\ ${ }^{3}$ IT-Breeding $\mathrm{GmbH}$, \\ Am Schwabeplan 1b, Gatersleben, Germany, 06466
}

\begin{abstract}
Aim. To study the influence of antibiotics Ceftriaxone and Timentin on the morphogenic calli and roots formation, shoots regeneration in two bread wheat cultivars Triticum aestivum L., to study effect of Ceftriaxone on the growth dynamics of plants. Methods. In vitro plant tissue culture, analysis of Variance, correlation and regression analysis. Results. The influence of $\beta$-lactam antibiotics Ceftriaxone and Timentin on morphogenetic processes (morphogenic calli formation, shoots regeneration and rhizogenesis), was studied in apical 18-day-old wheat calli. Two wheat genotypes of different growth habits, winter and winter-spring, were used. Conclusions. Timentin and Ceftriaxone stimulate morphogenic calli formation in bread wheat apical calli. As compared to Timentin, Ceftriaxone has strong concentration-dependent and genotype-dependent influence on shoots regeneration. The roots formation depended primarily on the wheat genotype, independently from an antibiotic applied. The presence of Ceftriaxone in culture medium stimulates rooting and growth of regenerating plants as well as their biomass increment.
\end{abstract}

Ke yw o r d s: Timentin, Ceftriaxone, morphogenic callus, shoots regeneration, root formation, plant growth dynamics, Triticum aestivum L.

\section{Introduction}

Plant tissue and organ culture is a powerful instrument of modern biotechnology. Biotechnology of bread wheat, which is one of the main sources of nutrients in the diet of mankind is developing intensely during the last few decades. Wheat in vitro culture is still at a stage of the improvement of existing techniques and development of new methods. Morphogenetic processes and, in particular, regeneration, are here under special attention since regeneration in wheat, like in many grasses is complicated.

Since the inception of plant cell, tissue and organ culture, antibiotics are widely used either as selective markers for genetic transformation (Kanamycin, Paromomycin, Hygromycin, etc.) or to eliminate any bacterial contamination (in particular during in vitro Agrobacterium-mediated transformation - Cefotaxime, Carbenicillin, etc.). Recently new generation antibiotics of the $\beta$-lactam group, such as Timentin and Ceftriaxone are used more often [1-11].

All researchers, which apply antibiotics when working with plant culture, report on their effects on the morphogenetic processes. In some cases the antibiotics Timentin and Ceftriaxone inhibit plant regeneration [35], in others - vice versa, increase it [6-13]. Accordingly, the objective of our study was to find out how antibiotics Timentin and Ceftriaxone affect morphogenic callus

(C) 2016 M. A. Bannikova et al.; Published by the Institute of Molecular Biology and Genetics, NAS of Ukraine on behalf of Biopolymers and Cell. This is an Open Access article distributed under the terms of the Creative Commons Attribution License (http://creativecommons.org/licenses/by/4.0/), which permits unrestricted reuse, distribution, and reproduction in any medium, provided the original work is properly cited 
development, shoot regeneration and root development in bread wheat, Triticum aestivum L. Effect of antibiotic Ceftriaxone on morphogenetic processes in wheat was studied for the first time, and the effect of Timentin has not been studied yet in bread wheat.

Plant sensitivity to antibiotics is not only speciesspecific, but also genotype-dependent, therefore in our study we used two wheat genotypes of different growth habit, winter wheat and winter-spring wheat. Although the $\beta$-lactam antibiotics are considered to be non-toxic to plants [12], many researchers have noted that their effect on the regeneration and morphogenesis may vary significantly depending on the plant species and the antibiotic concentration [14, 15]. Hence, in order to establish the pattern of action of the new generation antibiotics of $\beta$-lactam group on the morphogenetic processes (morphogenic callus development, shoot regeneration and rhizogenesis) in wheat, we used two antibiotics - Timentin and Ceftriaxone.

\section{Materials and Methods}

Effect of Timentin and Ceftriaxone on the morphogenic callus development (designated in tables and figures as "morphogenesis"), shoot regeneration and root development (development of the roots on the callus) was studied in 18-day-old wheat calli of apical origin, obtained according to [16].

We used calli of two wheat genotypes - cultivars Podolyanka (winter) and Zymoyarka (winterspring), the seeds of which were kindly provided by the Institute of Plant Physiology and Genetics, National Academy of Sciences of Ukraine, Kiev.

Previously, it was found that the highest regeneration frequency in wheat callus of apical origin was observed on the medium MSR4 [16]: up to $36 \%$ (average $-30.7 \pm 0.6 \%$ ) for Zymoyarka, and up to $33 \%$ (average $-30.8 \pm 0.4 \%$ ) for Podolyanka. This medium has become the basic and simultaneously the control medium in our research.

For studying the effect of different concentrations of antibiotics, initial calli (18-day old) were placed (50 samples per Petri dish) on the regeneration agar medium MSR4 which contained: MS salts [17],
Gamborg's vitamins [18], $20 \mathrm{mg} / \mathrm{l}$ sucrose, $10 \mathrm{mg} / \mathrm{l}$ $\mathrm{AgNO}_{3}, 0.5 \mathrm{mg} / \mathrm{l} \mathrm{BAP}$ and $0.15 \mathrm{mg} / \mathrm{l}$ picloram [16]. Timentin or Ceftriaxone were added to the MSR4 medium at a concentration of 25 to $500 \mathrm{mg} / \mathrm{l}$, in increments $25 \mathrm{mg} / \mathrm{l}$. Calli were cultured at $24{ }^{\circ} \mathrm{C}$ and 16 hour photoperiod during 30 days, every 14 days calli were transferred to the fresh medium. Experiments were conducted in three replicates.

Effect of antibiotics was assessed by three indicators (parameters):

- frequency of the morphogenic callus development, as a ratio of the number of callus explants with meristematic zones on $10^{\text {th }}-15^{\text {th }}$ day of cultivation, to the total number of initial callus explants,

- shoot regeneration frequency, as a ratio of the number of callus explants that formed shoots from $15^{\text {th }}$ to $30^{\text {th }}$ day of cultivation (counting was performed every 5 days), to the total number of initial callus explants,

- frequency of root development, as a ratio of the number of callus explants that formed roots on $15^{\text {th }}$ $30^{\text {th }}$ day of cultivation, to the total number of initial callus explants.

In addition to the study of the antibiotics effect on the morphogenetic processes in the initial callus, the effect of Ceftriaxone on the plant growth dynamics after the start of rooting was also studied. To study the growth dynamics, shoots, obtained on MSR4 medium supplemented with $400 \mathrm{mg} / \mathrm{l}$ of Ceftriaxone, were transferred to rooting medium which contained: MS salt, Gamborg's vitamins, 10 g/l glucose, $20 \mathrm{~g} / 1 \mathrm{maltose}$ and $0.15 \mathrm{~g} / 1$ asparagine monohydrate, [19]. Control shoots, obtained on the MSR4 medium without adding antibiotic, were transferred on the same medium. Antibiotics were not added in the rooting medium. Only those plants that had at least one root on $3^{\text {rd }}-4^{\text {th }}$ day after transfer to the rooting medium were used in the experiment. That is, the zero-day is the day when shoot formed the first root. Every five days after the appearance of the first root and up to 30 days, 5 control and 5 test plants were collected. Wet mass of shoot (the ground part) of regenerated plant and its separated roots were measured. Also the length of shoot and roots was mea- 
sured. Before weighing, the plants were washed from the agar medium and dried with a filter paper. After weighing, the plant material was placed in plastic bags with labels and dried by freeze-drying for 3-4 days (until constant weight) and re-weighted.

Relative increment was calculated for the wet and dry weights of plants and roots, shoot length, root length by the formula

$\boldsymbol{R} \boldsymbol{I}=\left(\boldsymbol{x}-\boldsymbol{x}_{0}\right) / \boldsymbol{x}_{0}$, where $\boldsymbol{x}$ - average growth rate value (root or plant dry or wet weight, root length, plant height), $x_{0}$ - the average value of the index at the beginning of the experiment, or on the day of rooting.

When creating scripts for the statistical data analysis and graphical plots, the standard functions in a programming language $\mathrm{R}$ [20] of the version 3.0.2. were used. For values, expressed as a percentage, previous logit transformation was applied.

\section{Results and Discussion}

The results on the influence of antibiotics Timentin and Ceftriaxone on the morphogenetic processes (morphogenic callus development, shoot regeneration and root development) in two wheat cultivars compared to the control are shown in Fig. 1 and Tables 1 and 2 (Supplementary materials).

\section{Morphogenic callus formation}

On the MSR4 medium without antibiotics (control) meristematic zones in the initial callus appeared on the $15^{\text {th }}$ day of cultivation (DoC), with the morphogenic callus development frequency 55,8 $\pm 1,8 \%$ for the cv Podolyanka and $76.6 \pm 2,1 \%$ for the $\mathrm{cv}$ Zymoyarka (Fig. 1 A, B) (Table 1, 2-Supplementary materials). If by the $15^{\text {th }}$ DoC meristematic zones were not formed in the initial calli, it remained nonmorphogenic until the end of the experiment (30 days).

When Timentin was added to the medium, meristematic zone in the initial callus also appeared on the 15th DoC, while with Ceftriaxone added - on the 10th DoC. The average frequency of the morphogenic callus development on the media supplemented with Timentin or Ceftriaxone shows significant increase, as compared to the control medium, in both cultivars (especially in the cv Podolyanka) (Fig. 1 A, B). Increased morphogenic callus development frequency is observed even at minimum concentrations of both antibiotics ( $25 \mathrm{mg} / \mathrm{l})$, and starting with $100 \mathrm{mg} / \mathrm{l}$ of antibiotics, morphogenic callus development frequency reaches the value of $>90 \%$ and remains as high irrespective of further increase of antibiotics concentrations.

Thus, we have shown that antibiotics Ceftriaxone and Timentin stimulate the morphogenic callus development, and Ceftriaxone additionally accelerates the appearance of the meristematic zones in the initial callus.

\section{Shoot regeneration}

Shoot regeneration dynamics were studied during the time interval from $15^{\text {th }}$ to $30^{\text {th }}$ DoC (Fig. 3, $4-$ Supplementary materials). First regenerated shoots appeared at the $21^{\text {st }} \mathrm{DoC}$ in the control medium, at the $18^{\text {th }}-20^{\text {th }}$ DoC - when Timentin was added to the medium, and at the $15^{\text {th }} \mathrm{DoC}-$ when Ceftriaxone was added.

Regeneration frequency on the MSR4 medium without antibiotics averaged for cv Podolyanka 25,5 \pm 2,4 \%, and for cv Zymoyarka 26,5 \pm 1,6 \% (Fig. 1 C, D). (See also Table 1, 2 - Supplementary materials).

Average regeneration frequencies of both wheat cultivars on the medium supplemented with Timentin showed no significant changes, except for the slight tendency for decreased regeneration frequency on the medium with the antibiotic, regardless of its concentration.

Adding Ceftriaxone to medium negatively affects shoot development in the cv Podolyanka in general. However, in the cv Zymoyarka Ceftriaxone in concentrations of 25-300 mg/l leads to an increase of shoot development frequency to $40 \%-50 \%$.

So, unlike Timentin, Ceftriaxone has obvious genotype-dependent influence on shoot regeneration in wheat (see also Fig. 5, 6 - Supplementary materials). The same concentrations of Ceftriaxone and Timentin have the opposite effect in cv Zymoyarka. For example, at a concentration of $75 \mathrm{mg} / 1$, Timentin suppresses regeneration and Ceftriaxone - increases.

Analysis of Variance confirmed the dependence of the regeneration frequency on several factors: the 


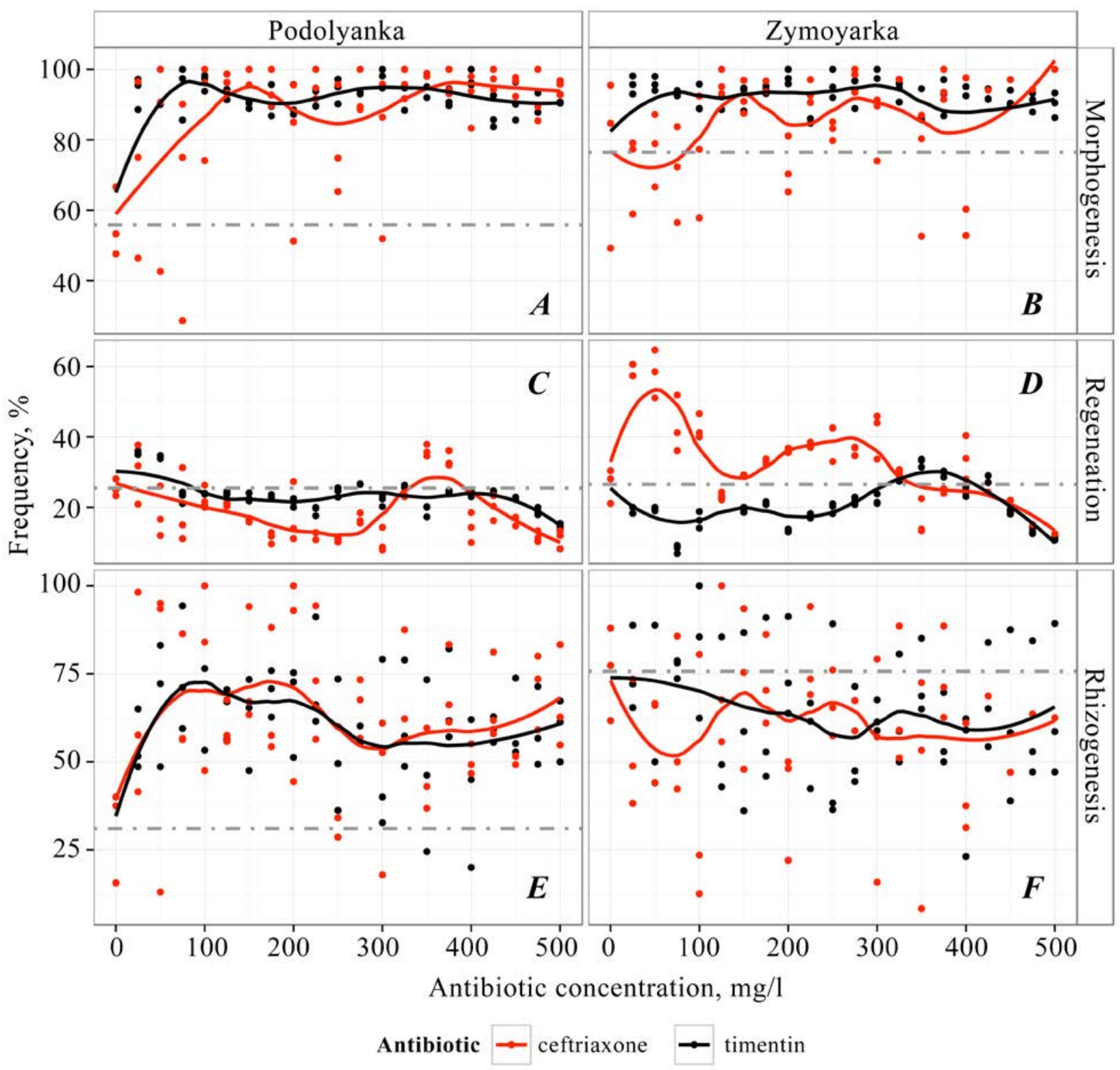

Fig. 1. Effect of antibiotics Ceftriaxone and Timentin on the frequency of meristematic islands appearance ("morphogenesis") in the initial callus, shoot regeneration ("regeneration") and root development in two bread wheat cultivars, Podolyanka (A, C, E) and Zymoyarka (B, D, F).

A, B - "morphogenesis" frequency at $10^{\text {th }}-15^{\text {th }}$ days of cultivation (DoC) in MSR4 medium, C, D - shoot regeneration frequency at $15^{\text {th }}-30^{\text {th }}$ DoC, E, F - rhizogenesis frequency at $15^{\text {th }}-30^{\text {th }}$ DoC.

Legend: point - the experimental data; dash-dotted line - mean value obtained for the antibiotic-free medium; continuous line smoothed conditional mean for morphogenic callus, shoots and roots development from callus.

plant genotype $(\mathrm{p}<0.05)$, the presence of the antibiotic in the medium, and in case of Ceftriaxone - the antibiotic concentration $(\mathrm{p}<0.001)$.
Thus, to achieve higher shoot regeneration frequencies, for every wheat genotype the specific $\beta$-lactam antibiotic and its concentration must be in- 
dividually selected, but all tested concentrations of Timentin and Ceftriaxone (25-500 mg/l) in the medium accelerated shoot regeneration.

\section{Rhizogenesis}

Root development frequency (development of the roots from the original callus) on the MSR4 medium without antibiotics averaged for cv Podolyanka 31,0土 1,6 \%, and for cv Zymoyarka 75,7 $\pm 2,7$ \% (Fig. 1 E, F). It should be noted that the root development frequency in the control was very high for cv Zymoyarka. (Table 1,2-Additional materials).

Analysis of averaged root development frequencies on the media supplemented with Timentin or Ceftriaxone showed that plant calli of cv Podolyanka and cv Zymoyarka reacted differently to the addition of antibiotics.

Adding Timentin to the medium significantly increases the frequency of rhizogenesis in cv Podolyanka, achieving $75 \%$ at concentrations of $75-225 \mathrm{mg} / \mathrm{l}$, and then decreasing to $55 \%$ at concentrations of $250 \mathrm{mg} / \mathrm{l}$ and higher. In cv Zymoyarka all tested concentrations of Timentin steadily lower the frequency of rhizogenesis, as compared to the control medium, to a value of 55-60\%.

Analysis of the average frequencies of root development on the medium supplemented with Ceftriaxone showed that this antibiotic significantly increases the root development frequency in cv Podolyanka, and reduces - in cv Zymoyarka, almost regardless of its concentration.

Analysis of Variance showed the dependence of root development frequency on the antibiotic concentration in the medium $(\mathrm{p}<0.005)$. The influence of other factors, and combinations thereof, on the rhizogenesis were within statistical error (Fig. 7, 8 - Supplementary materials).

Thus, root development frequency depends primarily on the genotype - on the control medium it is high in cv Zymoyarka and low in cv Podolyanka. Antibiotics of $\beta$-lactam group, Timentin and Ceftriaxone, have the opposite effect on root development frequency in two wheat cultivars.

It should be noted that under prolonged culture of calli with developed shoots on the MSR4 medium supplemented with Ceftriaxone, the rooting process begins. While first roots appeared at $21^{\text {st }} \mathrm{DoC}$ on the control MSR4 medium, adding antibiotics to the medium shifted the first roots development to the $20^{\text {th }}$ day $(350 \mathrm{mg} / \mathrm{l}$ of Timentin $)$ or to the $15^{\text {th }}-18^{\text {th }}$ day (25-500 $\mathrm{mg} / \mathrm{l}$ of Ceftriaxone).

Therefore, we can conclude that the antibiotic Ceftriaxone has a stimulating effect on the shoot regeneration and the plants regeneration in two wheat genotypes. It is possible for each genotype to select the concentration of the antibiotic that increases the regeneration frequency.

\section{Growth dynamics}

We observed that on the media supplemented with Ceftriaxone, regenerated shoots and plants grew faster than the control plants. They were larger, and were better adapted to the non-sterile growing conditions (Fig. 9 - Supplementary materials).

To confirm these observations, we measured a relative increase in plant biomass, plant height, root biomass and root length of regenerated plants. The results are presented in Tables 3 and 4 (Supplementary materials). The statistically processed data are presented in Figures 2 and 3 and in Tables 5-7 (Supplementary materials).

The graph of the relative increase in wet biomass (Fig. 2 A) can be divided into three stages: 1) exponential - from the beginning of the experiment until the fifth day after rooting, 2) linear - from the fifth to $20^{\text {th }}-25^{\text {th }}$ day, 3 ) exponential again - from the $20^{\text {th }}$ $25^{\text {th }}$ day until the $30^{\text {th }}$. During the $5^{\text {th }}-25^{\text {th }}$ day (Table 5 - Supplementary materials), there is a strong correlation (0.96-0.97) between the time of cultivation and the average relative increase of wet plant biomass. The angle of slope of the plot to the horizontal axis in the area of the $5^{\text {th }}-25^{\text {th }}$ day is corresponding to an average relative growth rate (RGR) of wet weight. RGR for the media containing Ceftriaxone is higher than in antibiotic-free media for Podolyanka (0.24 vs. 0.17 day $^{-1)}$, and for Zymoyarka (0.29 vs. 0.23 day $\left.^{-1}\right)$. The same is true for the dry biomass as well (Fig. 2 B), RGR for Podolyanka is 0.19 vs. 0.17 day $^{-1}$ and for Zymoyarka -0.24 vs. 0.20 day $^{-1}$, although the cor- 

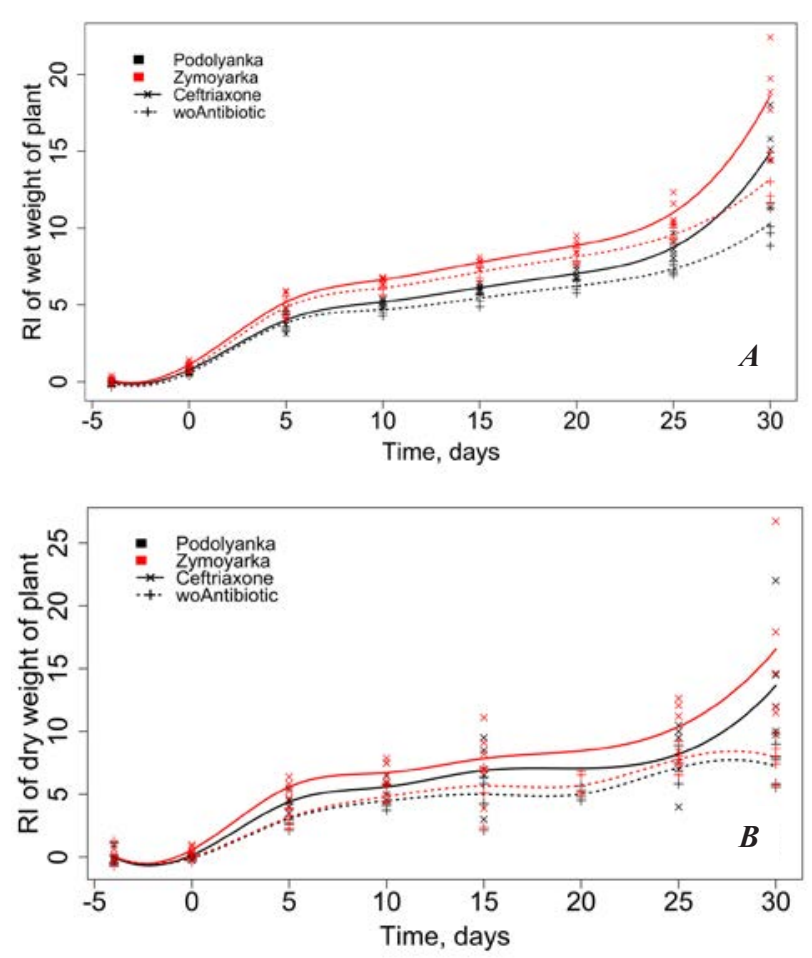

Fig. 2. The average relative increase (RI) of wet (A) and dry (B) mass of shoots (ground part) of regenerated plants of two bread wheat cultivars, Podolyanka (black) and Zymoyarka (red), obtained on the media either with $400 \mathrm{mg} / \mathrm{l}$ Ceftriaxone (solid line and the mark " $x$ ") or without the antibiotic (cross-hatching line and the mark "+"), depending on the culture period. Experimental data of individual measurements and smoothed line through the averaged frequency values are shown.

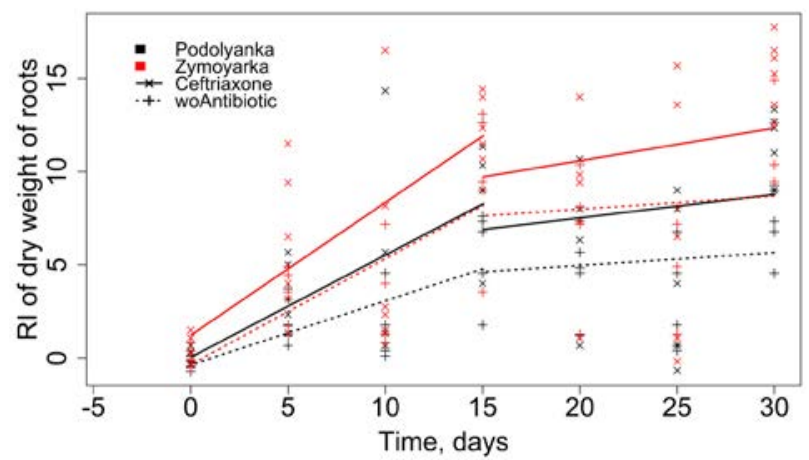

Fig. 3. Relative increment of the roots dry weight of regenerated plants in two wheat cultivars, Podolyanka (black) and Zymoyarka (red), obtained on media either supplemented with $400 \mathrm{mg} / \mathrm{l}$ Ceftriaxone (solid line and the mark "x"), or without it (cross-hatching line and the mark "+"), depending on the culture period. Experimental data of the individual measurements and results of the linear approximation by the method of least squares are shown.

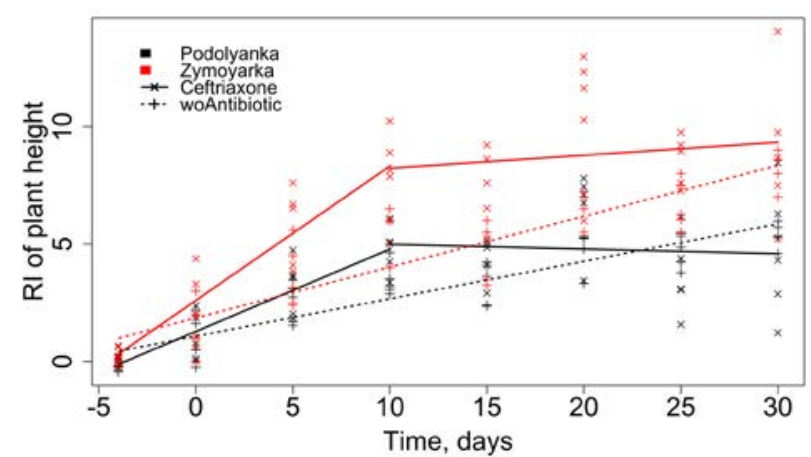

Fig. 4. Relative increment of regenerated plants height in two wheat cultivars, Podolyanka (black) and Zymoyarka (red), obtained on media either supplemented with $400 \mathrm{mg} / \mathrm{l}$ Ceftriaxone (solid line and the mark " $\mathrm{x}$ "), or without the antibiotic (crosshatching line and the mark "+"), depending on the culture period. Experimental data of individual measurements and linear approximation results by the method of least squares are shown.

relation coefficients are somewhat lower (from 0.61 to 0.79 )

The root system in both cultivars was developed within 15 days after the first signs of rooting, regardless of the presence of the antibiotic in medium. The average relative increment of the root system dry weight during the period was higher in the presence of Ceftriaxone for both Podolyanka $\left(0.55\right.$ day $\left.^{-1}\right)$ and Zymoyarka $\left(0.71\right.$ day $\left.^{-1}\right)$; on the antibiotic-free medium

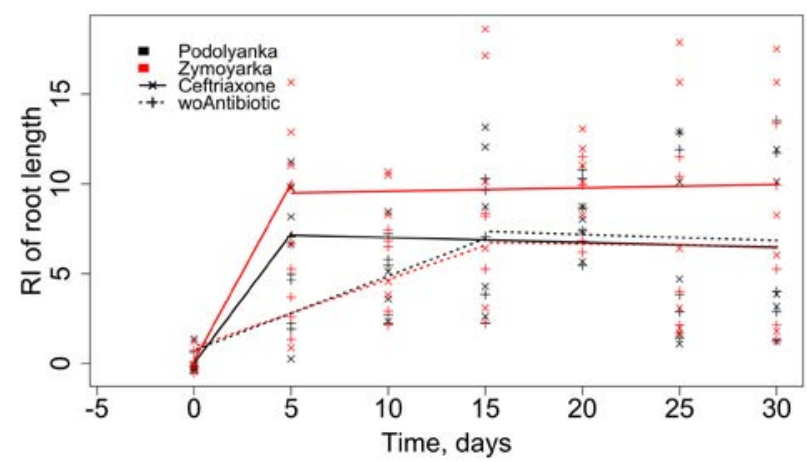

Fig. 5. Relative increment of the regenerated plants root length in two wheat cultivars, Podolyanka (black) and Zymoyarka (red), obtained in the media either supplemented with $400 \mathrm{mg} / \mathrm{l}$ Ceftriaxone (solid line and the mark "x"), or without the antibiotic (cross-hatching line and the mark "+"), depending on the culture period. Experimental data of individual measurements and linear approximation results by the method of least squares are shown. 
it was from 0.34 to 0.57 day $^{-1}$, respectively (correlation coefficient $\mathrm{R}=0,70-0,77)$. Importantly, the growth termination of the root system dry mass was noted either in the presence of the antibiotic, or without it, which led to the development of more advanced root system on the medium containing Ceftriaxone. During the period from the $15^{\text {th }}$ to the $30^{\text {th }}$ day, the average weight of roots on the antibiotic-containing medium was $2.675 \mathrm{mg}$ versus $2.225 \mathrm{mg}$ for cultivar Podolyanka, and $2.875 \mathrm{mg}$ versus $2.025 \mathrm{mg}$ - for cultivar Zymoyarka. A similar pattern was observed for the wet roots weight.

Also heights of plants grown on the medium without antibiotic and supplemented with Ceftriaxone were measured (data are presented in Tables 3 and 4 (Supplementary materials). The processed data of the regenerated plants height relative increment are shown in Figure 4 and Table 8 (Supplementary materials).

Plant height increase on the antibiotic-free medium was linear throughout the whole experiment (Fig. 4), as evidenced by the high correlation coefficients (0.90 and 0.91), despite the lower RGR: 0.16 vs. 0.35 for Podolyanka and 0.22 vs. 0.57 for Zymoyarka. Due to prolonged growth period, the plants shoots height on the antibiotic-free medium and on the antibiotic-containing medium was almost similar at the end of the experiment.

The fastest shoot growth on media containing Ceftriaxone was observed between the time of transfer to the rooting medium and up to the $10^{\text {th }}$ day of cultivation (Fig. 4), after which the growth slowed down or suspended. The negative value of the average relative growth rate (RGR) of cultivar Podolyanka shoot length during the period from the $10^{\text {th }}$ to the $30^{\text {th }}$ day is due to the fact that the measurements were done not for the same plant during the experiment, but for randomly selected groups, and as from the $10^{\text {th }}$ day shoot growth stopped, a plant having a lower height could get in the group, measured later.

A similar pattern was observed for the root length growth (Fig. 5) Table 9 (Supplementary materials). During the first 5 days, a rapid growth of roots from shoots grown on the media supplemented with antibiotic. Roots of shoots, grown on the medium without an antibiotic, grew slightly slower. Subsequently, the roots of shoots, which were grown on the antibiotic-free medium, grew at slower rate.

Thus, it can be concluded that the presence of antibiotic Ceftriaxone in the medium for shoots development, stimulates both the growth of the regenerated plants and their biomass increase.

Antibiotics Timentin and Ceftriaxone, belonging to the $\beta$-lactams, are used to treat a range of infectious diseases in humans. These antibiotics are active in vitro against most gram-negative and gram-positive microorganisms. It was found that the $\beta$-lactam antibiotics cause lysis of bacteria by inhibiting such enzymes as transpeptidase and carboxypeptidase, catalyzing the synthesis of peptidoglycan [1].

A target for $\beta$-lactams in the plant body is not established yet. Most probably, the effect of antibiotics Timentin and Ceftriaxone on plants is due to their similar chemical structure to auxin [12]. It is considered that Ceftriaxone is able to induce the formation of phenylacetic acid, a weak natural auxin [15]. Thus, we can assume that antibiotics Timentin and Ceftriaxone can imitate plant growth regulators and act as weak auxins.

It is not possible to exclude the interaction of antibiotics and their degradation products with endogenous hormones of plant cells [15, 21-23], or with the components of culture medium (BAP or picloram in this case).

Timentin is used in plant in vitro culture for a long time. The first publications on the application of Timentin date back to 1997 [10]. Ceftriaxone became common in the Agrobacterium-mediated plant transformation rather recently $[1,2,4,5]$.

There is discordant evidence about the dependence of the effect of Timentin and Ceftriaxone on morphogenetic processes in different plant species on their concentration.

It is known that $\beta$-lactam antibiotics adversely affect the regeneration of explants cultured in vitro: Ceftriaxone at a concentration of $400 \mathrm{mg} / \mathrm{l}$ completely inhibits blueberry shoots growth [4], $200 \mathrm{mg} / 1$ - suppresses leaves, petioles and stems regeneration of ox knee (Achyranthes bidentata) [5]. High concentrations of Timentin (500-1000 mg/l) in 
culture medium, as well as all $\beta$-lactams, decrease the somatic embryoids regeneration in walnut [3].

In some cases Timentin $(250 \mathrm{mg} / \mathrm{l})$ has no negative effect on the callus growth, for example, in rice (Oryza sativa L.) [6]. There are reports that Timentin stimulates morphogenetic processes in plants [713]. It increases organogenesis from leaf explants of tobacco Nicotiana tabacum (150 mg/l) [10] and cotyledon of tomato explants $(300 \mathrm{mg} / \mathrm{l})$ [11], callus formation of mature wheat germ $(50 \mathrm{mg} / \mathrm{l})$ [9], shoots regeneration from strawberry leaf explants (300 mg/l) [13] and the regeneration of white ash (Fraxinus americana) (500 mg/l) [7], efficient plant regeneration from protoplasts of three carrots cultivars (400-500 mg/l) [12] and the shoot induction in tomato $(400 \mathrm{mg} / \mathrm{l})$ [8].

It is established that the influence of Timentin on regeneration processes depends on its concentration in culture medium $[14,15]$ : during shoots regeneration of London plane tree (Platanus acerifolia Willd) from leaf explants, Timentin in concentration of 100 and $500 \mathrm{mg} / \mathrm{l}$ adversely affects plant regeneration, and in concentration of $300 \mathrm{mg} / 1$ - significantly increased shoot regeneration frequency [14]; during hypocotyls and cotyledons regeneration of teak (Tectona grandis) Timentin in concentration of $100-300 \mathrm{mg} / \mathrm{l}$ stimulated shoots regeneration, and in concentration $500 \mathrm{mg} / 1$ induced excessive calli formation, but inhibited regeneration [15]. These data confirm our observation that Timentin in high concentrations inhibits regenerative processes, and in average - can stimulate them.

Si-Nae Han [9] found that in durum wheat cultivars Keumkangmil, Alchanmil and Bobwhite, Timentin influence was manifested as follows: the highest callus development frequency was observed in concentration of $50 \mathrm{mg} / 1$, and the regeneration frequency - at $500 \mathrm{mg} / \mathrm{l}$. Moreover, Timentin in high concentrations (500 mg/l) accelerated shoots formation from mature wheat germ [9]. These data are in conflict with ours - Timentin in high concentrations $(500 \mathrm{mg} / \mathrm{l})$ in culture medium inhibits the regeneration processes in bread wheat.

In two tomato cultivars, rooting of shoots that were regenerated on Timentin-supplemented medi- um was observed. Moreover, rooting was occurred on both Timentin-supplemented medium and Timentin-free medium [11]. We observed a similar phenomenon for rooting of wheat on Ceftriaxonesupplemented medium - antibiotics induce a mechanism of roots formation, and their presence in a medium was no longer necessary.

Although Ceftriaxone is already being used to eliminate $A$. tumefaciens during genetic transformation of wheat germ [1] and lettuce cotyledons Lactuca sativa [2], its impact on plants is not studied. We did not find any information about the positive effect of Ceftriaxone on morphogenetic processes in plants.

In our research comprehensive and consistent investigation of Timentin and Ceftriaxone effect on morphogenetic processes in two bread wheat genotypes was carried out for the first time. We have established the regeneration frequency dependence on three factors: the antibiotic and its concentration in culture medium, and the plant genotype. Considering our results, it is clear why the data of other authors look contradictory. We can confirm that all of the researchers, who claimed that Timentin raises or lowers the regeneration of different plant species, were right, because antibiotic effect obviously depends on the plant species and plant genotype characters.

\section{Conclusions}

Antibiotics Timentin and Ceftriaxone are able to affect the morphogenetic processes in bread wheat apical calli. However, although both antibiotics belong to $\beta$-lactams, they have different influence. Both antibiotics stimulate the morphogenic calli development and Ceftriaxone also accelerates the meristematic zones appearance in the initial calli. Moreover, a) to stimulate morphogenic calli development higher concentrations of Ceftriaxone than of Timentin are required; b) to increase the morphogenic calli development frequency, Timentin supplementation to the nutrient medium is important, and not its concentration.

The influence on shoot regeneration frequency depends on the antibiotic (Timentin or Ceftriaxone), 
and in the case of Ceftriaxone - its concentration matters. Unlike Timentin, Ceftriaxone shows obvious genotype-dependent influence on shoot regeneration in wheat. Timentin and Ceftriaxone in the same concentrations exert opposite effects on the studied wheat genotypes: the first one increases regeneration frequency, while the second - decreases. Thus, to achieve higher shoot development frequency for each wheat genotype a $\beta$-lactam antibiotic and its concentration must be individually selected, but adding of Timentin or Ceftriaxone in all tested concentrations $(25-500 \mathrm{mg} / \mathrm{l})$ accelerates shoots regeneration.

The root development frequency depends primarily on the wheat genotype - in one cultivar (Zymoyarka) it is initially high, in the other (Podolyanka) low. The root development frequency decreases in Zymoyarka and increases in Podolyanka when adding the $\beta$-lactam antibiotics.

The presence of Ceftriaxone in culture medium stimulates rooting, growth of regenerated plants and their biomass growth. Thus, Ceftriaxone is promising antibiotic for wheat in vitro culture.

\section{Funding}

The work was supported by National Academy of Sciences of Ukraine and completed in the framework of the scientific project «Using molecular and cellular technologies for biotech wheat and maize plants resistant to the herbicide glyphosate obtaining» (0115U004187).

\section{REFERENCES}

1. Yarizade A, Aram F, Niazi A, Ghasemi Y. Evaluation of effect of $\beta$-lactam antibiotics on suppression of different strains of Agrobacterium tumefaciens and on wheat mature embryo culture. Iran J Pharm Sci. 2012; 8(4):267-76.

2. Fallah-Ziarani M, Haddad R, Garoosi Gh, Jalali M. Agrobacterium-mediated transformation of cotyledonary leaf of lettuce (Lactuca sativa L.) by the GCHI gene. Iran J Pharm Sci. 2013; 2(2):47-55.

3. Tang H, Ren Z, Krczal G. An evaluation of antibiotics for the elimination of Agrobacterium tumefaciens from walnut of somatic embryos and for the effects on the proliferation of somatic embryos and regeneration of transgenic plants. Plant Cell Rep. 2000;19(9):881-7
4. Zhao $X$, Zhan L-P, Zou X-Z. Improvement of cold tolerance of the half-high bush Northland blueberry by transformation with the LEA gene from Tamarix androssowii. Plant Growth Regul. 2011; 63(1):13-22.

5. Duan HY, Ding XS, Song JY, He YL, Zhou YQ. Plant regeneration and Agrobacterium-mediated transformation of Achyranthes bidentata using cotton EREBP gene. Braz Arch Biol Technol. 2013; 56(3):349-56.

6. Priya A, Pandian SK, Manikandan R. The effect of different antibiotics on the elimination of Agrobacterium and high frequency Agrobacterium-mediated transformation of indica rice (Oryza sativa L.). Czech J Genet Plant Breed. 2012; 48(3):120-30

7. Palla KJ, Pijut PM. Agrobacterium-mediated genetic transformation of Fraxinus americana hypocotyls. Plant Cell Tiss Organ Cult. 2015; 120(2):631-41.

8. Mamidala P, Nanna $R$. Influence of antibiotics on regeneration efficiency in tomato. Plant Omics J. 2009; 2(4):135-40.

9. Han $S-N$, Oh P-R, Kim H-S, et al. Effects of antibiotics on suppression of Agrobacterium tumefaciens and plant regeneration from wheat embryo. J Crop Sci Biotech. 2007; 10(2):92-8.

10. Nauerby $B$, Billing $K$, Wyndaele $R$. Influence of the antibiotic Timentin on plant regeneration compared to Carbenicillin and Cefotaxime in concentrations suitable for elimination of Agrobacterium tumefaciens. Plant Sci. 1997; 123(1-2):169-77.

11. Costa MGC, Nogueira FTS, Figueira ML, Otoni WC, Brommonschencel SH, Cecon PR. Influence of the antibiotic Timentin on plant regeneration of tomato (Lycopersicon esculentum Mill.) cultivars. Plant Cell Rep. 2000; 19(3):327-32.

12. Grzebelus E, Skop L. Effect of $\beta$-lactam antibiotics on plant regeneration in carrot protoplast cultures. In Vitro Cell Dev Biol Plant. 2014;50(5):568-75.

13. Haddadi F, Aziz MA, Abdullah SN, Tan SG, Kamaladini $H$. An efficient Agrobacterium-mediated transformation of strawberry cv. Camarosa by a dual plasmid system. Molecules. 2015;20(3):3647-66.

14. Li Z, Liu G, Fang F, Bao M. Adventitious shoot regeneration of Platanus acerifolia Willd. facilitated by Timentin, an antibiotic for suppression of Agrobacterium tumefaciens in genetic transformation. Forestry Studies in China. 2007; 9(1):14-8.

15. Tambarussi EV, Rogalski M, Nogueira FTS, Brondani GE, De Martin VF, Carrer H. Influence of antibiotics on indirect organogenesis of Teak. Ann For Res. 2015; 58(1):177-83.

16. Gorbatyuk IR, Gnatyuk IS, Bannikova MA et al. Effect of synthetic auxin-like growth regulators on callus regenerative ability of bread weat cv. Zymoyarka. Plant Physiology and Genetics, 2015; 47(6):514-25.

17. Murashige T, Skoog F. A revised medium for rapid growth and bioassays with tobacco tissue cultures. Physiol Plant. 1962; 15:473-97.

18. Gamborg $O L$, Eveleigh DE. Culture methods and detection of glucanases in cultures of wheat and barley. Can J Biochem. 1968; 46(5):417-21. 
19. Sidorov V, Duncan D. Agrobacterium-mediated maize transformation: immature embryos versus callus. Methods Mol Biol. 2009;526:47-58.

20. Ihaka $R$, Gentleman $R$. A language for data analysis and graphics. J Comput Graph Stat. 1996; 5(3):299-314.

21. Holford P, Newbury HJ. The effects of antibiotics and their breakdown products on the in vitro growth of Antirrhinum majus. Plant Cell Rep. 1992;11(2):93-6.

22. Ling H-Q, Kriseleit D, Ganal MW. Effect of ticarcillin/potassium clavulanate on callus growth and shoot regeneration in Agrobacterium-mediated transformation of tomato (Lycopersicon esculentum Mill.). Plant Cell Rep. 1998; 17(11):843-7.

23. Souza Canada ED, Beck E. Embryogenic callus induction on the scutellum and regeneration of plants as basis for genetic transformation of spring wheat (Triticum aestivum L.) cultivars from Argentina. BAG J Basic Appl Genet. 2013; 24(2):55-66.

Вплив антибіотиків цефтріаксону і тиментину на морфогенетичні процеси в культурі in vitro м'якої пшениці Triticum aestivum L.

М. О. Банникова, I. Р. Горбатюк, І. С. Гнатюк, Л. В. Малишева-Отто, В. П. Дуплій

Мета. Вивчити вплив антибіотиків тиментину та цефтріаксону на утворення морфогенного калюсу, регенерацію пагонів і ризогенез у двох сортів м'якої пшениці Triticum aestivum L., вивчити вплив цефтріаксону на динаміку росту рослин. Методи. Культура тканин рослин in vitro, дисперсійний та кореляційно-регресійний аналізи. Результати. Вивчено вплив антибіотиків бета-лактамів цефтриаксону і тиментину на морфогенетичні процеси (утворення морфогенного калюсу, регенерацію пагонів і ризогенез), що відбуваються в 18-добовому калюсі м'якої пшениці апікального походження. Використані два генотипи пшениці різного типу розвитку - озима та озимояра. Висновки. Тиментин і цефтріаксон стимулюють утворення морфогенного калюсу апікального походження м'якої пшениці, а цефтріаксон також прискорює появу меристематичних зон в калюсі. Характер впливу на частоту регенерації пагонів залежить від антибіотика (тиментин або цефтріаксон). Вплив цефтріаксону на регенерацію пагонів залежить від генотипу рослини та від концентрації антибіотика. Частота ризогенезу залежить в першу чергу від генотипу м'якої пшениці незалеж- но від використаного антибіотика. Наявність цефтріаксону в культуральному середовищі, на якому були отримані пагони, стимулює укорінення і ріст рослин-регенерантів, а також приріст їх біомаси.

К л юч о в і с л о в а: тиментин, цефтриаксон, морфогенний калюс, регенерація пагонів, ризогенез, динаміка росту рослин, Triticum aestivum $\mathrm{L}$.

\section{Влияние антибиотиков цефтриаксона и тиментина на морфогенетические процессы в культуре in vitro мягкой пшеницы Triticum aestivum $\mathrm{L}$}

М. А. Банникова, И. Р. Горбатюк, И. С. Гнатюк, Л. В. Малышева-Отто, В. П. Дуплий

Цель. Изучить влияние антибиотиков тиментина и цефтриаксона на образование морфогенного каллуса, регенерацию побегов и ризогенез у двух сортов мягкой пшеницы Triticum aestivum L., изучить влияние цефтриаксона на динамику роста растений. Методы. Культура тканей растений in vitro, дисперсионный и корреляционно-регрессионный анализы. Результаты. Изучено влияние антибиотиков бета-лактамов цефтриаксона и тиментина на морфогенетические процессы (образование морфогенного каллуса, регенерацию побегов и ризогенез), происходящие в 18-суточном каллусе мягкой пшеницы апикального происхождения. Использованы два генотипа пшеницы разного типа развития разного направления - озимая и озимо-яровая. Выводы. Тиментин и цефтриаксон стимулируют образование морфогенного каллуса апикального происхождения мягкой пшеницы, а цефтриаксон также ускоряет появление меристематических зон в каллусе. Характер влияния на частоту регенерации побегов зависит от антибиотика (тиментин или цефтриаксон). Влияние цефтриаксона на регенерацию побегов зависит от генотипа растения и от концентрации антибиотика. Частота ризогенеза зависит в первую очередь от генотипа мягкой пшеницы независимо от использованного антибиотика. Наличие цефтриаксона в культуральной среде, на которой были получены побеги, стимулирует укоренение и рост растений-регенерантов, а также прирост их биомассы.

К л юч е в ы е с л о в а: тиментин, цефтриаксон, морфогенный каллус, регенерация побегов, ризогенез, динамика роста растений, Triticum aestivum L. 